\author{
Albert Zahtila \\ E-mail: albert.zahtila@gmail.com \\ Z.M. Developement d.o.o., Puntižela 46, HR-52100 Pula, Croatia \\ Elvis Zahtila \\ E-mail: elvis.zahtila@natura-histrica.hr \\ Public institution „Natura Histrica“, Riva 8, HR-52100, Pula, Croatia \\ Roko Dejhalla \\ E-mail: roko.dejhalla@riteh.hr \\ University of Rijeka, Faculty of Engineering, Vukovarska 58, HR-51000 Rijeka, Croatia
}

\title{
Artifficial Reefs - New Habitats of Marine Life
}

\begin{abstract}
The aim of this paper is to analyze the problem of artificial reefs, to warn to the need for definition of such facilities in the national legal framework and in the context of urban ecology, present their potential for the marine environment. A review and analysis of national legal frameworks and European regulations regarding the possibilities of their establishment and management is given, all towards to reduce the eutrophication process, the increase of the fish stock and the creation of a zone for the prohibition of fishing in order to protect the coastline and enable the renewal of marine biodiversity and ecosystems in Republic of Croatia.
\end{abstract}

Keywords: artificial reefs, potential, legal framework, Republic of Croatia

\section{Introduction}

The first artificial reef was set up in the middle of 19th century in the United States, but the expansion of this activity came in the sixties of the last century when many artificial reefs were planed, constructed and set up in the world seas. Thus, more than three hundred sites with artificial reefs have been set so far along the Atlantic coast of the North American continent, most of them near the coast of Florida [1]. With regard to the construction and materials from which they are made, two basic approaches can be distinguished. Initially, due to lower price, the most diverse metal and concrete waste of larger dimensions were used: shipwrecks, car tires, metal pipes, motor vehicles etc. An underwater photo of the Osborne Reef is shown in Figure 1 [2]. Today, the 
special concrete elements which form the so-called fish houses almost exclusively are used [3]. An example of artificial reef concrete module is shown in Figure 2 [4]. The main advantages of such facility consisting of custom made concrete elements are an acceptable ecological and aesthetic aspect, an efficient catchment area for fish, crabs, mollusks, then the possibility of controlled molluscs farming in the reef zone and efficient protection of the coastal sites from overfishing with towed fishing tackle tools.

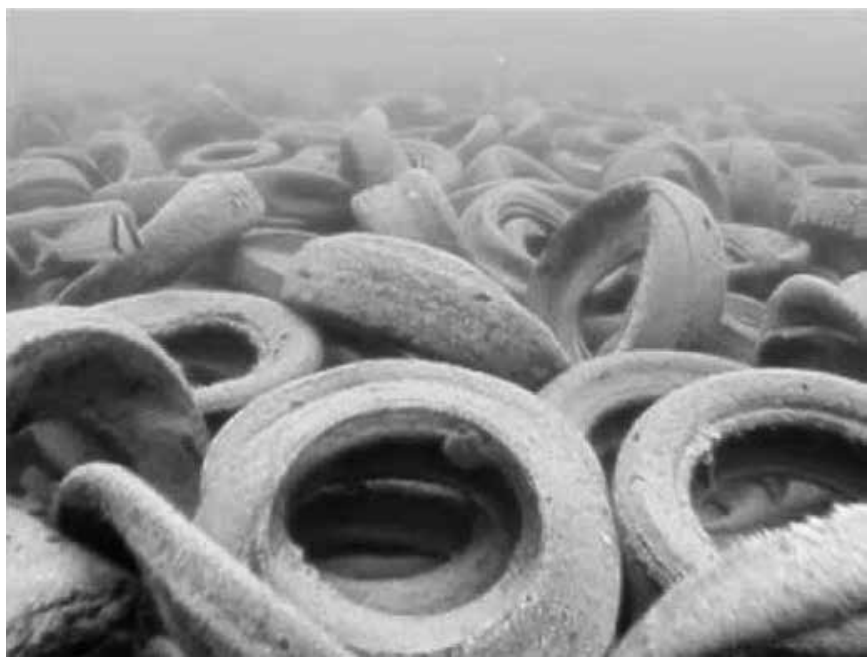

Figure 1: An underwater photo of the tires constituting Osborne Reef [2]

The oldest artificial ridge closest to the Republic of Croatia was set up in 1970 near the Italian city Genoa. It consisted of 1,300 car wrecks. As corrosion has drastically reduced the effects of setting up such a reef, Italian experts have decided to setup a concrete reef. Since 1977, artificial reefs have been built in the vicinity of the Italian city Ancona as a part of a long-term coastal zone improvement program [5]. The objective of this program was to reuse of sea energy (nutrients, organic matter) that concentrates along the coast due to increased human activities, then to increase the number of favorable living habitats for particular marine organisms, to extend the shelters of species that need protection for offspring and the protection of the seabed and localities of small coastal fisheries by pulling fishing gear.

The commercial effects of the reef area which, for example, occupies three hectares are significant. For example, mussels settle with density of 130 to 200 tons per year, the average yield of oysters is 20 tons per reef, the production of various fish species is increased by more than 10 tons per year. Also, on $100 \mathrm{~m}$ fishnets that are used in small coastal fishing, an average catch of 30 kilograms of the highest quality fish is achieved. Positive results are noticed by all fishing associations along the coast and they increasingly participate in the financial support of such projects because it is proven that total cost of reef is compensated in a few years [6]. 


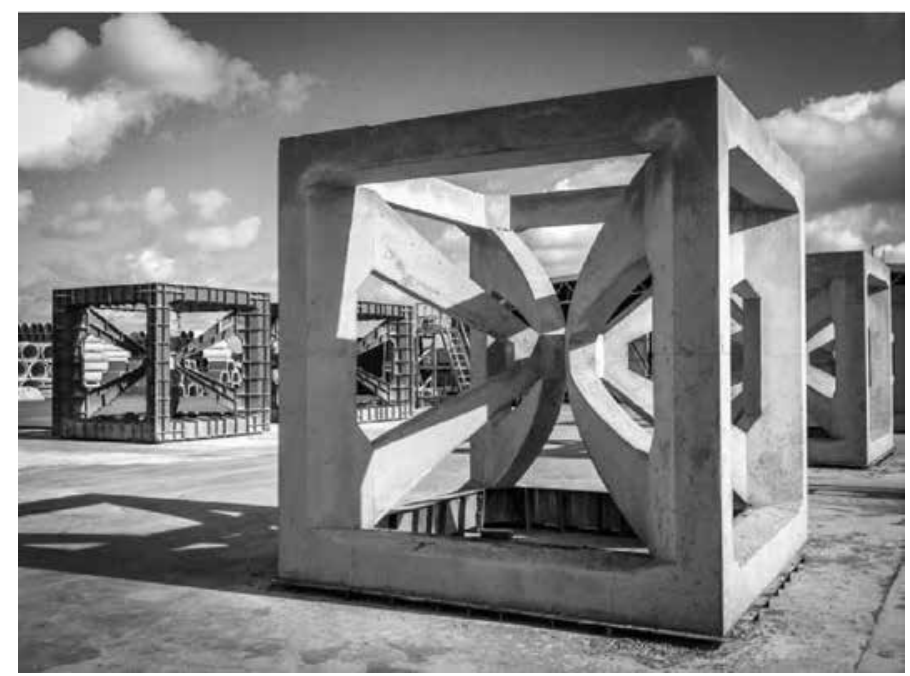

Figure 2: An example of artificial reef concrete module [4]

Artificial reefs serve as a base for acceptance and development of shellfish, then as a breeding ground for fish or as a barrier that prevents the entry of trawlers into the coastal zone and thus contributes to the survival of the juvenile fish species. Also, an added benefit about these underwater facilities is that they precipitate the rejuvenation of the marine environment. Today, in some parts of the world, their role in recreation and development of tourism is increasing. For example, artificial reefs can be specially designed to create waves needed for "surfing", while another role can be to protect the shore from erosion caused by strong waves.

The artificial reefs as one of the way of reducing the consequences of eutrophication in the sea were investigated in the bay of Trieste [7]. The eutrophication is the process in which the water transparency is reduced, the excessive algal blooms appears, the mucus accumulate and there is an oxygen deficiency. An example of eutrophication is shown in Figure 3.The idea is quite simple and is based on the natural potential of marine organisms. Many organisms that inhabit these facilities feed by filtration of sea water. They exploit nutrients from the sea whilst reduce their total amount and in this manner improve the sea conditions in general. This is of exceptional importance because shallow coastal waters are ecologically and economically most important part of the marine ecosystem and at the same time its most sensitive part [8]. The consequences of eutrophication are most felt as reduced transparency of sea water, phytoplankton flowering, mucus formation, lack of oxygen, seabed on sea bottom etc. 


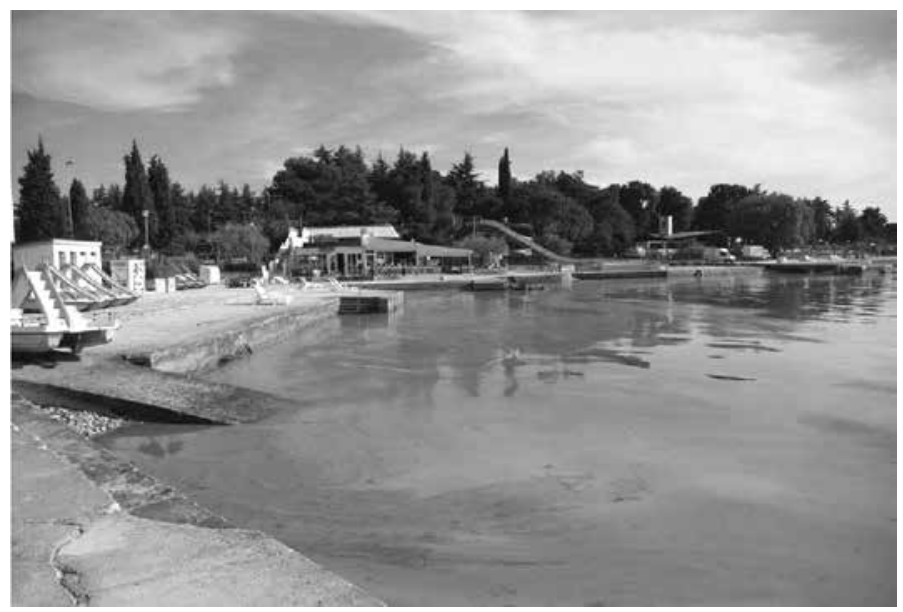

Figure 3: An eutrophication in the city of Poreč, Republic of Croatia

\section{Legal framework in Republic of Croatia}

About the selection of sites and the installation of artificial reefs in the Republic of Croatia (RH) there is no practical experience and the legal framework is insufficient or not in line with EU legislation. Opinions and recommendations on artificial reefs in the RH are very contradictory. Thus, the National Environmental Protection Strategy [9], quite contrary to the positive world experiences, opposes the setting of artificial reefs, describing them as "an unnatural and violent method of rapid recovery of the fish stock" that "needs to be resolved as it will irretrievably destroy Croatian undersea and can also cause unforeseeable disturbances in the ecosystem". No explanation is given for such an attitude and it is not clear how the artificial reefs can destroy the underwater if natural and/or appropriate artificial materials are used. At the same time, with permits acquired form port authorities or competent ministries, in the sea is deposited the material obtained by deepening or cleaning ports or sea areas that are later used for the construction of ports, nautical centers, industrial zones, etc. The quantities of such displaced sediments may be more than hundreds of thousands cubic meters. Ultimately, such deposited material disperses in a very wide area and is deposited on the seabed, alters its morphology and covers the existing living communities and thus irreversibly changes habitats. At the same time, it puts out a lot of different large waste into the sea but also nutrients and many possible harmful substances.

On December 20,2014, the Act on Marine Fisheries [10] came into force, which defined the term „artificial reef" as "artificially established submarine habitat, most commonly by immersion of ships, stone blocks or other similar objects" and thus laid the legal foundation for setting artificial reefs. However, in the new Act on Marine Fisheries [11], which came into force on July 8, 2017, the definition of the 
term "artificial reef" was excluded. Instead, in the part III "Measures to manage the biological resources of the sea", article 12, paragraph 1, for the points 10 ("plans for recovery of stocks and shellfish settlements") and 11 ("special measures required to reduce the effects of fishing activities on the marine ecosystem") it is quoted (paragraph 3 ) that ordinances referred to, in paragraph 1, points 10 and 11 of this article shall be prescribed by the minister with the prior opinion of the minister responsible for the nature protection. The minister is obliged to adopt implementing regulations within two years from the entry into force of this act.

With this new Act on Marine Fisheries, the laws of the European Parliament and of the Council, No 508/2014 and No 498/2007 have been taken into account in the part of structural policy and market regulation, state aid to fisheries, and management and protection of renewable biological resources, thus providing a legal framework for determining the competent authorities and their tasks in these segments.

In the Regulation (EU) No 508/2014 of the European Parliament and of the Council of 15 May 2014 on the European Maritime and Fisheries Fund [12] it is written in the article Article 40 "Protection and restoration of marine biodiversity and ecosystems and compensation regimes in the framework of sustainable fishing activities", paragraph 1: "In order to protect and restore marine biodiversity and ecosystems in the framework of sustainable fishing activities, with the participation, where relevant, of fishermen, the EMFF may support ... (b) the construction, installation or modernization of static or movable facilities intended to protect and enhance marine fauna and flora, including their scientific preparation and evaluation ". In the same document, in the article 44 "Inland fishing and inland aquatic fauna and flora), in the paragraph 6 it is written: ,In order to protect and develop aquatic fauna and flora, the EMFF may support... (b) the construction, modernization or installation of static or movable facilities intended to protect and enhance aquatic fauna and flora, including their scientific preparation, monitoring and evaluation ".

Regulation (EU) No 498/2007 of the European parliament and of the Council of 26 March 2007 [13], Article 16 - Measures intended to protect and develop aquatic fauna and flora: establishes the support concern measures for the construction and installation of artificial reefs or other facilities made up of long lasting elements.

The article 18 of the Spatial plan of the Istrian County [14] enables that "in specially explored and justified locations, at the level of spatial plans of cities and municipalities, new artificial reefs can be planned in order to expand the potential habitats of particularly valuable benthos communities as well as to reduce devastating influence of the sea on the beaches and coast".

\section{Guidelines for construction and installation of artificial reefs}

When considering the construction and installation of the artificial reef, the following items shall be considered: 
- The area is not part of the protected area according to the Act on Environmental Protection [9] and according to the Act on Marine Fisheries [11]

- The artificial reef should not endanger protected species and/or habitats,

- The artificial reef should not interfere with the existing marine traffic,

- The locations where undersea cables and pipelines are laid as well as where hydro-archeological sites are located shall be avoided,

- The artificial reef should be built from a material that is ultimately nonaggressive (i.e. PH neutral) to the marine environment,

- The sea is publicly available to everyone and no concessions should be required for the installation or management of artificial reefs,

- Before the installation and the exploitation it is required to conduct researches related to the control of fouling and settlement of the reef, the rate of settling and the species which inhabit,

- After the installation, the monitoring of new substrates and settlements of a new habitat should be carried out with monitoring of basic hydrographic parameters, sea dynamics and biocenological tests.

The analysis regarding the selected location for the artificial reef shall include the following:

- Spatial planning analysis,

- Analysis of basic hydrographic parameters

- Sea dynamics: sea currents, tides, etc.,

- Living communities at the seabed ("in situ"): description of communities, spatial layout, diversity of flora and fauna, types of species which have commercial and recreational values

- Sediment analysis: granulometric composition, organic matter in sediment, quantity and description of heavy metals in sediment.

\section{Conclusion}

Coastal waters are the most important marine ecosystem in ecological and economic sense. At the same time, this area unfortunately becomes more and more vulnerable every day. Eutrophication is one of the biggest threat. The authors have an opinion that a public should fight not only against the obvious consequences of eutrophication but also against its causes. The simplest and most effective method is to exploit the natural abilities of marine organisms that filter sea water and thus remove the unwanted substances. The special underwater structures - artificial reefs - enhance the creation of such organisms. Such a facility is considered the only possible strategy that can improve the quality of the marine environment once the nutrients are accumulated into the sea. Also, the reef can create a kind of barrier to the coastal belt that and thus prevent overfishing with towed fishing tackle tools. 
The new Act on Marine Fisheries of the Republic of Croatia from 2017 still does not recognize artificial reefs as a way of restoring marine biodiversity and ecosystems. However, there is an obligation to adopt implementing regulations within two years from the entry of this act into force which directly concerns the protection and renewal of marine biodiversity and ecosystems. The regulations should support the construction of such structures, including their scientific preparation and evaluation.

Because of the relatively large dimension and total mass of underwater artificial reefs, there is a need to give a special attention to the design and building technology due to its complexity of installation on the seabed. The entire system should be fully modular and customizable and should fit into the marine environment and moreover it should in no case interfere with the existing marine infrastructure and traffic.

\section{Literature}

1. OFFICER, C. B., R. B. BRIGGS, J.L. TAFT, L. E. CRONIN, M. A. TYLER \& W. R. BOYNTON, 1984. Chesapeake Bay Anoxia: Origin, Developement, and Signifiance. Science, 223: 22-27

2. Osborne Reef, http://blog.zingarate.com/wanderlustt/osborne-reef, accesed October 2017.

3. GROVE, R. S., C. J. SONU, \& M. NAKAMURA, 1991. Design and engeneering of manufactured habitats for fisheries enhacement. Seaman Jr., W. \& Sprague, L. M. (eds.), Artificial habitats for marine and freshwater fisheries. Academic press, 109-152

4. WA South West Artificial Reef Project, http://haejoo.com/projects/the-south-west-artificial-reefproject-western-australia/, accesed October 2017.

5. BRAMBATI, A. (ED.) 1988. Il fenomeno del ,mare sporco“ nell'Adriatico. Consiglio Nazionale delle Ricerce, Progetto Strategico Oceanografia e Technologie Marine. Trieste-Roma. 68 pp.

6. FOND, U., 1995. Umetni podvodni grebeni - ena izmed možnosti za vzdrževanje biotske raznovrstnosti v slovenskem morju. Annals for Istrian and Mediteranean Studies 7: 231-234

7. BOMBACE, G. 1989. Artificial reefs in the Mediterranean Sea. Marine Science 44: 1023-1032

8. UNESCO reports in marine science 49. Eutrophication in the Mediterranean Sea: receiving capacity and monitoring of long-term effects 1988, 195.

9. Nacionalna strategija zaštite okoliša, Narodne novine 46/02, 2002.

10. Zakon o morskom ribarstvu, Narodne novine 81/13, 14/14, 152/14, 2014.

11. Zakon o morskom ribarstvu, Narodne novine 62/17, 2017.

12. Regulation (EU) No 508/2014 of the European Parliament and of the Council of 15 May 2014 on the European Maritime and Fisheries Fund and repealing Council Regulations (EC) No 2328/2003, (EC) No 861/2006, (EC) No 1198/2006 and (EC) No 791/2007 and Regulation (EU) No 1255/2011 of the European Parliament and of the Council, Official Journal L 149, 2014

13. Commission regulation (EC) No 498/2007 of 26 March 2007 laying down detailed rules for the implementation of Council Regulation (EC) No 1198/2006 on the European Fisheries Fund, Official Journal L 120, 2007.

14. Prostorni plan Istarske županije, Službene novine Istarske županije, br. 14/2016, 2016. 
Albert Zahtila, Elvis Zahtila, Roko Dejhalla

\section{Umjetni grebeni - nova staništa morskih organizama}

\section{Sažetak}

Cilj ovog rada je analizirati problematiku umjetnih morskih grebena, upozoriti na potrebu za definiranjem takvih objekata u nacionalnom zakonskom okviru te u kontekstu urbane ekologije, predstaviti njihov potencijal za morski okoliš. Dan je pregled i analiza nacionalnih zakonskih okvira i europskih propisa koji se tiču mogućnosti njihovog postavljanja i upravljanja, a sve u cilju smanjenja procesa eutrofikacije, povećanja ribljeg fonda te formiranje zone zabrane ribolova radi zaštite priobalnog pojasa i omogućavanja obnove morske bioraznolikosti i ekosustava u Republici Hrvatskoj.

Ključne riječi: umjetni morski greben, potencijal, zakonski okvir, Republika Hrvatska 